\title{
Kirilli ja Methodiuse püha Ukrainas Bessaraabias ja Krimmis ${ }^{1}$
}

\begin{abstract}
Ekaterina Anastasova
Teesid: Kirilli (Cyril) ja Methodiuse (Mefodi) püha (11.-24. maini) ning kahe pühakust venna elu ja töö on Bulgaaria rahva paradigmas kesksel kohal. Nende elu ja tööd tähistavad kõik slaavi rahvad (rahva- või kirikukalendris erinevate rõhuasetustega ja eri kuupäevadel). Ka bulgaaria diasporaa Ukrainas (kõige suurem bulgaaria kogukond väljaspool Bulgaariat) tähistab seda püha ja sellel on oma koht riigi ametlikus kalendris.

Artikkel käsitleb püha tähistamist Ukrainas Bessaraabias (Odessa) ja Krimmis (Sevastopol) elavate bulgaarlaste ja ukrainlaste seas, kahe pühakust venna elu ja päritolu tõlgendamist, nende tööd ja tähendust slaavi kultuurile mõlemas kogukonnas (bulgaarlastel ja ukrainlastel). Analüüs näitab kahe pühaku elu ja töö tõlgendamise dünaamikat erinevate rahvaste paradigmas ja riigi prioriteetides.

Märksõnad: Euroopa Liit, püha Clemens, pühakud Kirill ja Methodius, Ukraina taasärkamine, Venemaa
\end{abstract}

Kirilli ja Methodiuse ning nende järglaste töö - glagoolitsa ja slaavi kirjakeele loomine, kristliku kirjanduse tõlkimine, kristluse levitamine ja slaavikeelse liturgia tutvustamine - on vorminud slaavlaste ajaloo varasel ajajärgul nende identiteedi. Nagu on väitnud Nikita Tolstoi, "andis slaavi tähestiku ja kirjakeele loomine uue tõuke üldslaavilikule eneseteadvuse tõusule ja slaavlaste koha mõistmisele teiste rahvaste seas" (Tolstoi 1988: 136). Vendade kultus on slaavi rahvaste renessansi ja moderniseerumise ajal uuenenud ja sellest on saanud mitme slaavi rahva rahvuslik paradigma. Ühest küljest on see tingitud kirjasüsteemi ja kirjaliku kultuuri põhiolemusest rahvusliku identiteedi tekkes, teisest küljest valdkonnast, milles kaks venda oma valgustustegevust arendasid. Ruum, kus Kirilli ja Methodiuse idee levib, on suur - Thessalonikist, kus nad sündisid², läbi Hersonesose, Kasaaria ja Alaania, Rooma, Määrimaa, Pannoonia ja Baieri nende õpilaste rajatud kirjakoolideni tänapäeva Bulgaaria ja Makedoonia aladel. 
Kinnituse vendade kultuse olulisuse kohta annab kahe venna tunnistamine õigeusu (Vene Õigeusu kirik 1863. aastal) ${ }^{3}$ ja katoliku kiriku (1880) pühakuks, samuti asjaolu, et "slaavlasest paavst" Johannes Paulus II kuulutas nad 1980. aastal ühinenud Euroopa kaitsjateks.

Nende austamine pole seotud üksnes traditsioonilise renessansiga, vaid laiema Euroopa ja 20. sajandi lõpu uute slaavi demokraatiatega.

Keskaja, rahvusliku taassünni paatose ja tegelikkuse kombinatsioon määrab ära kahe venna kultuse kaks peamist mõõdet käesoleva artikli kontekstis:

- pühakute rituaalse kummardamise vormid (püha Kirilli ja Methodiuse püha): religioosne ja ilmalik, s.o ametlik ja rahvuslik hariduse ja kultuuri päev (slaavi, bulgaaria jne) ning õpilaste koolivaba päev;

- kahe venna kultuse kasutamine poliitilises ja geopoliitilises kontekstis.

Kirilli ja Methodiuse ideele Ukrainas keskendume kahest peamisest vaatepunktist: kultus ja püha kui osa ukraina rahvuslikust kultuurist ja bulgaaria diasporaa kultuur Ukrainas (suurim bulgaaria diasporaa välismaal). Käesoleva artikli materjali on kogutud 2009. aastal välitöödel Odessas ja Sevastopolis, andmed Kirilli ja Methodiuse kultuse kohta tänapäeva Ukrainas (2014).

\section{Ajalooline kontekst: Ukraina ida ja lääne vahel ning rahvuslik mitmekesisus}

Arvestades sisepingeid ja geopoliitilist orientatsiooni on Ukraina üks keerulisematest postsovetlikest piirkondadest. Euroopa suuruselt teise riigi suundi ja meeleolusid määravad ajaloolised asjaolud. Etümoloogiliselt seostub riigi ajalooline nimi piiri peal olemisega: Ukraina ${ }^{4}$ - “у-края” (lõpus, ääre peal, piiri peal), Malorussija (Väike-Venemaa), ${ }^{5}$ Novorussija (Uus-Venemaa).

Samuel Huntingtoni määratluse kohaselt kuulub Ukraina geopoliitilise struktuuri raames, mis jagab maailma tuumikriikide ümber koondunud tsivilisatsioonideks, nn karistusväärsete riikide hulka. Euroopa on tema (ja mitte ainult tema) arvamuse kohaselt jagunenud lääneks (lääne-kristlik) ja idaks (õigeusk ja islam). Selle kontseptsiooni sees on Ukraina jagunenud lääneks (ukrainakeelne ja "natsionalistlik" uniaatlik ${ }^{6}$ ala) ning idaks (vene keelt kõnelev ja õigeusklik ala). Esimene peab eesmärgiks läänt, teine Venemaad, õigeuskliku maailma tuumikriiki (Huntington 1999: 220-238). Pärast Nõukogude Liidu lagunemist on Ukraina üks kõige ebastabiilsemaid riike, mis tuleneb tema geopoliitilisest asendist (Anastasova 2012b: 269-278).

Selgub, et arutelu Ukraina suundumuse (kas Venemaa või Euroopa Liidu poole) üle tõuseb haripunkti koos Ukraina iga vastvalitud valitsuse orientat- 
siooni teemaga. Aastal 2009, mil ma oma uurimust läbi viisin, oli Ukraina valimiste ootel. 2013. aastal nurjas Euroopa-meelse ja Vene-meelse Ukraina vastasseis Euroopa Liiduga kavandatud lepingu allakirjutamise, mis tõi kaasa Maidani sündmused ning pika ja verise kodusõja (2014).

Riigi paljurahvuseline koosseis tuleneb otseselt geopoliitilisest kontekstist. Pärast Nõukogude Liidu lagunemist ja Ukraina iseseisvumist valis Ukraina rahvusriigi tee, s.t eristatakse rahvusvähemusi (Ukraina terminoloogias rahvuslik-kultuurilisi vähemusi), kelle tegevust rahastab (küll minimaalselt) riik (Anastasova 2005: 59-65). Lisaks põhilisele etnilisele (ja lingvistilisele - kuni linnades domineerib vene keel) vastasseisule venelaste ja ukrainlaste vahel (2001. aastal oli ukrainlasi $77,8 \%$ ja venelasi $17,3 \%$ ) on rahvastikuküsimus Ukrainas seotud riigi suurte paljurahvuseliste piirkondadega, nagu seda on ka meie vaatlusalused Bessaraabia ja Krimm.

Bessaraabias Odessa piirkonnas on registreeritud 123 etnilist kogukonda, ${ }^{7}$ samal ajal vene keelt kõnelev Krimm (autonoomne vabariik 1991. aastast) on kogenud nii dramaatilist "ukrainastamist" kui ka pärast Teist maailmasõda Jossif Stalini käsul deporteeritud ja Mihhail Gorbatšovi perestroika ajal rehabiliteeritud krimmitatarlaste naasmist.

Nii Bessaraabia kui ka Krimmi bulgaarlased on oluline rahvusvähemus (2001. aasta rahvaloenduse andmeil on Ukrainas üle 200000 bulgaarlase, kes elavad peamiselt Odessa ja Zaporižžja piirkonnas). Bessaraabia bulgaarlaste domineerimine mõlemas piirkonnas on tingitud asjaolust, et pärast Krimmist deporteerimist on ainult väike osa Krimmi bulgaarlastest sinna naasnud. Bulgaarlased osalevad nii Ukraina igapäevastes poliitilistes debattides kui ka rahvusvähemuste elavdamise protsessis postsovetlikus piirkonnas (Anastasova 2012b). Ukrainas tegutseb mitmeid bulgaarlaste etnilisi organisatsioone, bulgaaria keelt õpetatakse koolides ja ülikoolides, ilmuvad bulgaariakeelsed raamatud ja ajalehed.

Mõlemad protsessid - sõltumatu Ukraina rajamine ja vähemuste taassünd tekitavad pingelise "uue arusaama" minevikust ("oma ajaloost" - riigi ja rahvuse omast) ja riigi kultuurist, mis rahvusliku ülesehitusprotsessi loogika kohaselt peegeldub peamiselt koolide õppekavades ja õpikutes. Soov eemalduda Vene (Nõukogude) ajaloost ja ajalookirjandusest viib uute tõlgendusteni, mis peegeldavad meeleolusid riigis. Võib tuua mitmeid näiteid (kangelaste ja antikangelaste ümberhindamine, "monumentide sõda" jne). Nagu on kokkuvõtlikult öelnud Valeri Kerov:

Pärast NSV Liidu lagunemist [endisteks Nõukogude vabariikideks - autori märkus] on väga kiiresti kirjutatud oma rahvusliku ajaloo õpikuid... [---] Esitrükid ei tuginenud oma riigi uuele akadeemilise teaduse saavu- 
tustele. [---] Hiljem kirjutatakse uued algupärased õpikud, mis põhinevad akadeemilistel uuringutel ja üldtuntud faktide korrektsetel tõlgendustel. Nende raamatute autorid esitavad sageli uue riikliku staatuse omandanud territooriumide ajaloo kohta suuremal või vähemal määral ajaloolisest tegelikkusest eemaldunud Vene-vastase iseloomuga mütologiseeritud ideid.

Ukraina uues hariduskirjanduses hakkavad Vene ajaloo fragmendid värvuma Ukraina toonidesse. Nii kõnelevad Jaroslav Tark, Vladimir Monomahh ja teised Kiievi vürstid "iidses ukraina keeles” [---]. Üldjoontes räägitakse isegi 10.-12. sajandi vene ja ukraina kultuurist Mihailo Gruševski ${ }^{8}$ kontseptsiooni kohaselt. Alajaotuses "Ukraina kirjandus" mainitakse sellised "Ukraina kirjandustegelasi" nagu Theophanes Prokopovitš, Dmitiri Rostovski, teadlasi ja haridustegelasi, kaasa arvatud Vene esimese matemaatikaõpiku autor L. Magnitski, filoloog I. Sreznevski jt. Loomulikult oli Ivan Fedorov esimene ukraina kirjastaja jne (Kerov 2013: 124).

Ukrainastamise ja slaavi ühtsuse konteksti mahutuvad ka vennad Kirill ja Methodius. Nagu muudeski riikides, on ka Ukraina päritolul (pärand) oma ajalugu ja geograafia. Odessa piirkonnas, eriti Krimmis algab see looga Rooma Clemensist, nagu seda on kajastanud "Itaalia legend" (Legenda Italica).

\section{Püha Rooma Clemens, Constantinus ${ }^{9}$ (Kirill) ja Methodius Krimmis}

Elulooliste andmete kohaselt ristis paavst Clemens I (Rooma paavst Clemens), kristliku märtri, kes suri umbes 101. aastal pKr, apostel Peetrus ise. Clemensi elu ja teenistus on olnud seotud Rooma kiriku, Krimmi ja Kiievi Venemaaga.

Rooma Clemensi lugu tema elukirjelduses langeb peaaegu sõna-sõnalt kokku lugudega, mida on rääkinud Sevastopolis küsitletud (kes on kursis mitte üksnes looga, vaid ka Krimmi topograafiaga), samuti looga, mis on käibel tänapäeva Ukraina ametlikus kontseptsioonis.

Jutluste ja ristimiste tõttu Roomas saatis keiser Traianus Clemensi Inkermani marmorikaevandusse (praegu Inkermani linn, mis asub Hersonesose lähedal Krimmis ${ }^{10}$ ), kus ta jätkas jutlustamist, paganlike pühamute hävitamist ja imetegude sooritamist. Jumala ingli abiga, kes nimetab ennast lambukeseks, avastas pühak janustele kiviraiduritele allika. Pärast seda hakkas ta ristima rohkem kui 500 inimest päevas. Raevunud keiser määras Clemensile valuliku surma: ta pidi seotama ankru külge ja uputatama merre. Tänu Clemensi jüngrite palvetele avanes meri pärast tema hukkamist igal aastal üheks nädalaks 


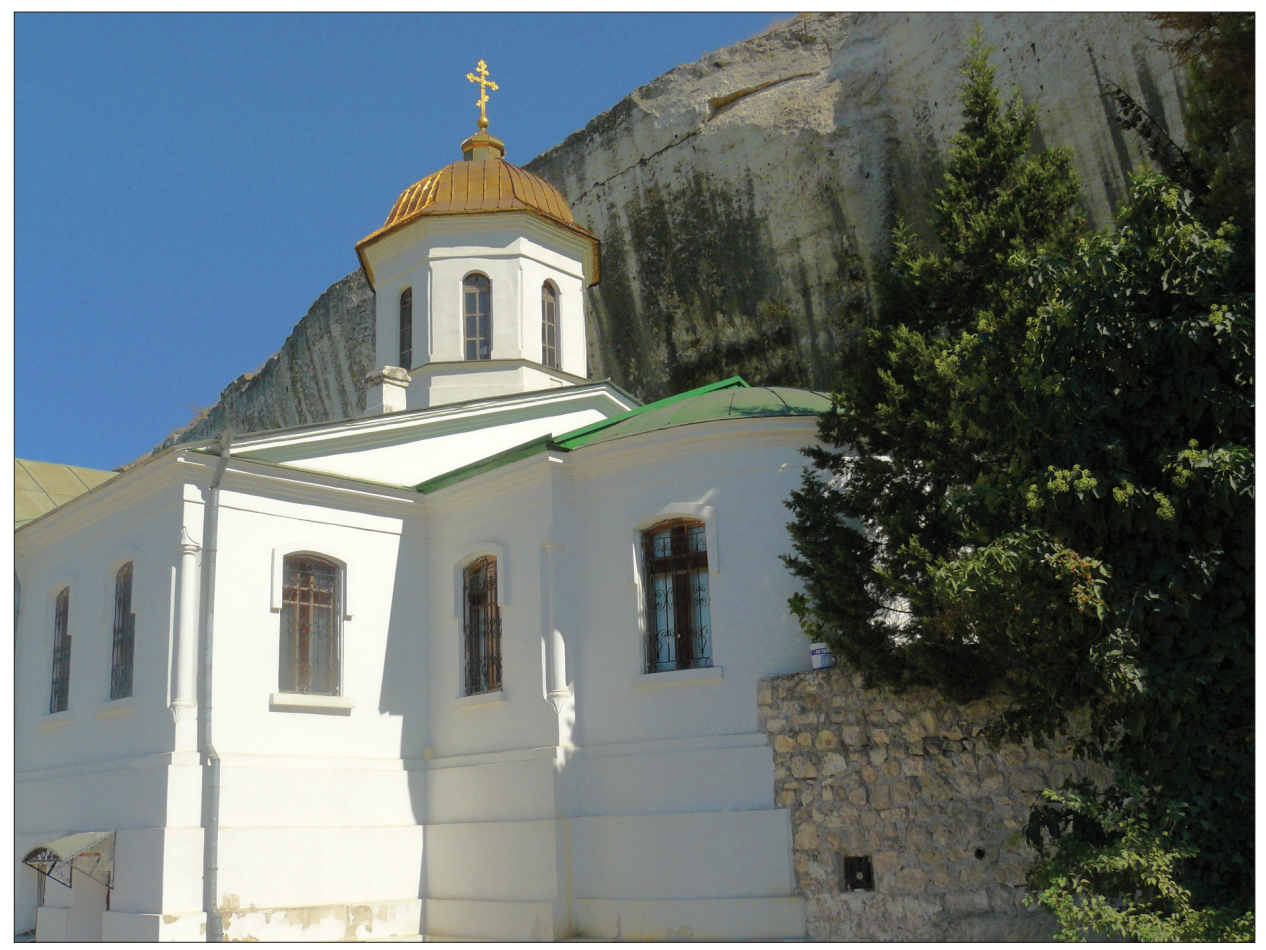

Foto 1. Püha Clemensi klooster Inkermani linnas (Krimm). Ekaterina Anastasova foto 2009.

ja paljastas pühaku imelise marmorhaua, mille läheduses võis näha ankrut, millega koos ta uputati. Usklikud kõndisid merre ja kummardasid pühakut. Haua läheduses leidis aset mitmeid imesid: tervenemisi, deemonite väljaajamisi jne. Imed jätkusid seitse sajandit.

Et veenda kasaari khaane ühinema kristlusega, saadeti filosoof Constantinus aastal 860 pKr Bütsantsi naabrusse kasaaride juurde, kus üksteise kõrval esinesid võrdsena kolm religiooni - judaism, kristlus ja islam -, samuti olid esindatud paljud paganlikud kultused. Ta läks koos Methodiusega, peatudes peaaegu aasta Hersonesose Taurises (tänapäeva Sevastopoli läheduses), kus õppis heebrea keelt, et suuta osaleda kasaari preestritega peetavates teoloogilistes dispuutides. Jõudnud Hersonesosse, asus Constantinus otsima pühaku haua asukohta ning kohalikest vaimulikest ja ilmikutest entusiastidega avastas ta 30. jaanuaril 861 esimese ribi ning hiljem pühaku terviklikud säilmed. ${ }^{11}$ Pärast Moraavia missiooni viisid vennad pühaku säilmed Rooma (aastal 868 pKr). 


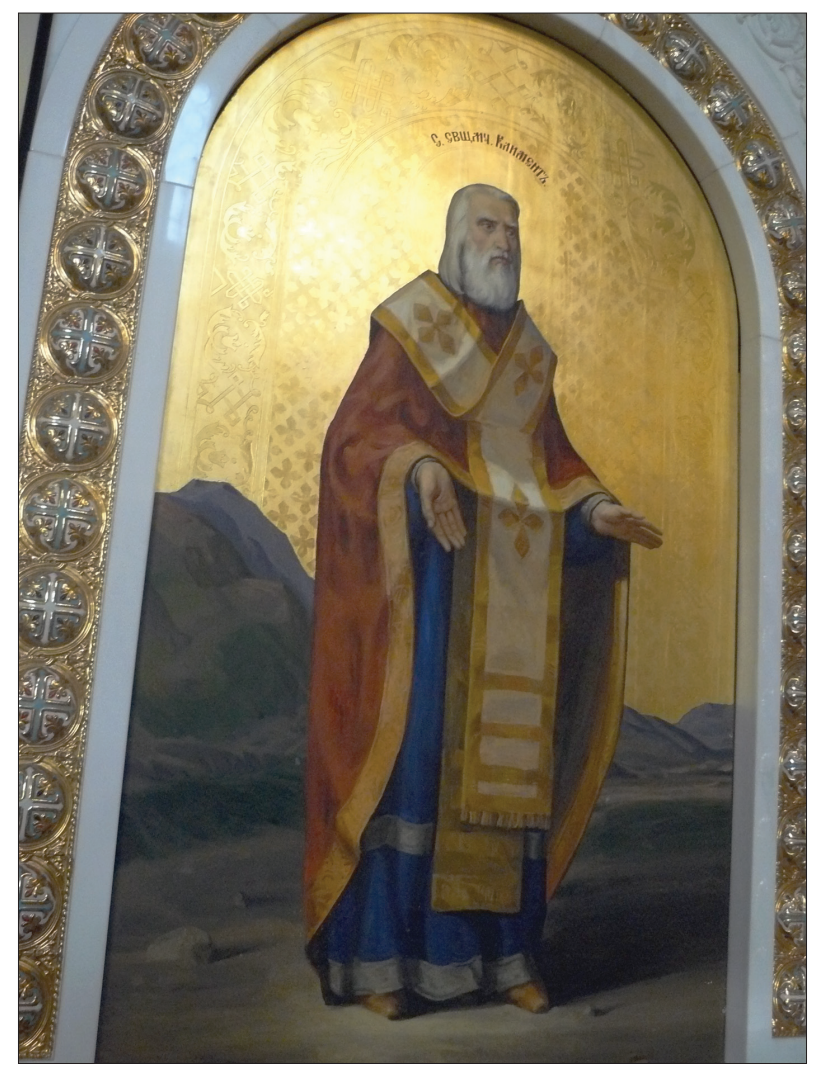

Foto 2. Püha Clemensi seinamaal püha vürst Vladimiri kirikus Hersonesoses, Sevastoopol. Ekaterina Anastasova foto 2009.

Tema pea jäi aga Hersonesosesse. Hiljem, pärast seda, kui ta oli Hersonesoses ristiusku pööratud, viis Kiievi vürst Vladimir (umbes 950-1015), Venemaa ristiusustaja, Clemensi pea Kiievisse.

Need sündmused on määrava tähtsusega püha Clemensi ning püha Kirilli ja Methodiuse austamisel Sevastopolis, mis asub Hersonesos Taurise lähedal, ja Inkermanis. Kirilli ja Methodiuse populaarsust varjutab püha Clemens, keda Krimmi asukad väga kõrgelt hindavad.

Ekspertide hinnangul on püha Clemensi lugu täiesti erinev. Kohaliku (Hersonesose) Clemensi austamine on Krimmis põimunud Ankara Clemensi austamisega. Viimane on maetud Ankarasse (Galatea), kus Bütsantsi pärimuse kohaselt suri Rooma Clemens. Ankara Clemensi säilmed viidi Hersonesosse. Paganad viskasid need merre ja säilmed jätkasid imetegusid. Puuduvad kindlad 


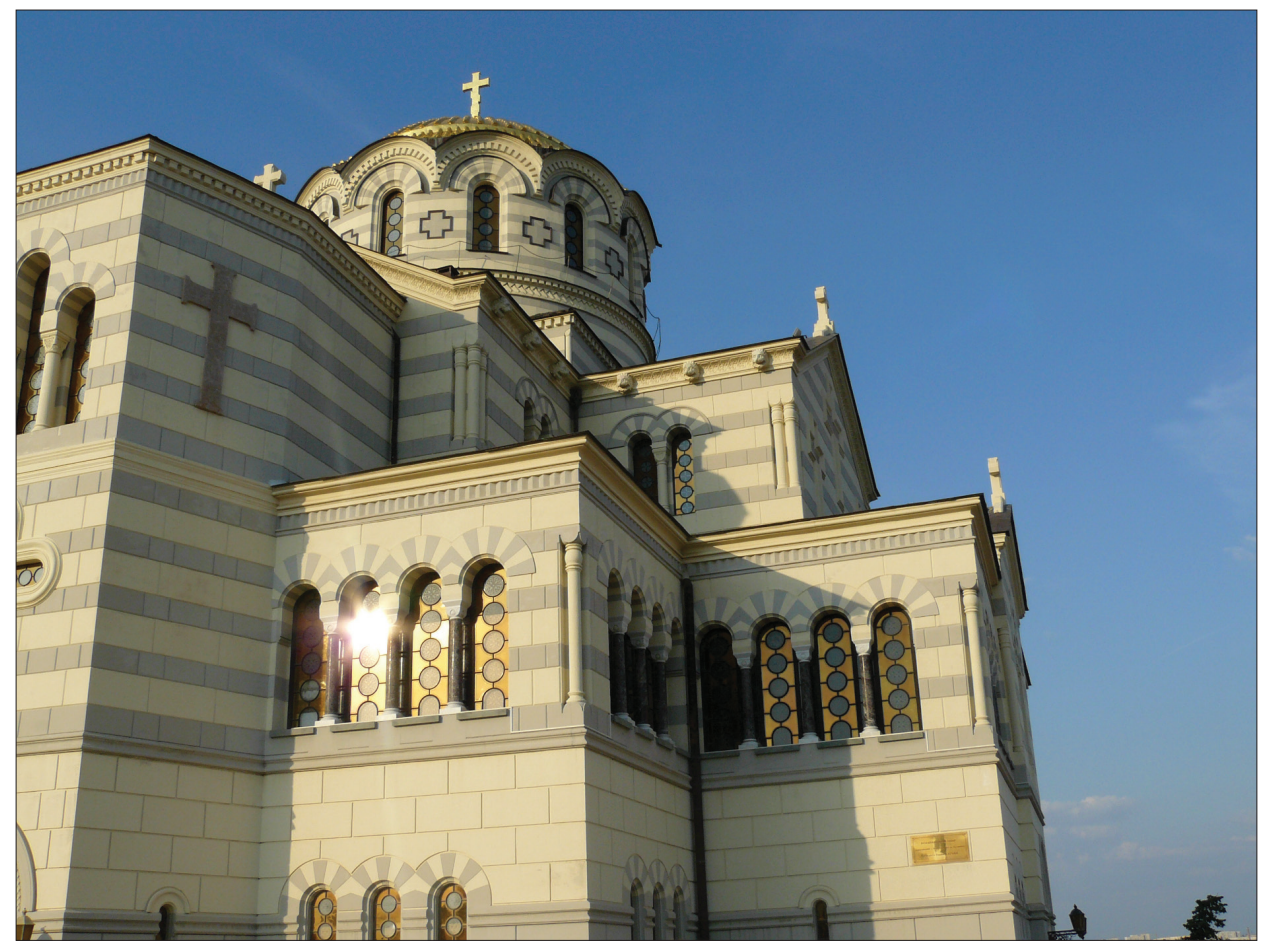

Foto 3. Püha vürst Vladimiri kirik Tauria Hersonesoses, Sevastoopol. Ekaterina Anastasova foto 2009.

ajaloolised tõendid, et püha Rooma Clemens oleks surnud märtrisurma (kuid ta ei surnud oma voodis, nagu on kinnitanud varasemad allikad) ja et ta üldse oleks kunagi Krimmis viibinud (vt nt ajalugu püha Rooma Clemensi elu kohta Spiridonov $^{12}$ 1909: 115-124).

Pühak on tänini Sevastopolis väga populaarne ja tema oletatavat surmakohta peetakse endiselt au sees. ${ }^{13}$ Püha Clemensi koobast Inkermanis külastatakse sageli, kuivadel kevadetel (1970. aastatel) arvati seal olevat pühaku avastatud veesoon.

Rooma Clemensi elu seostub ida- ja läänekiriku ajalooga tänapäeva Krimmis, Ukrainas ja Venemaal huvitaval kombel hilisema geopoliitilise "mõra" (Huntingtoni terminoloogia) joontega selles piirkonnas.

Ootuspäraselt hõlmab rahvuslik ülesehitusprotsess Ukraina ja Venemaa kristlike pühakute "natsionaliseerimist". 22. augustil 2011 püstitati Venemaal Moskva jõe äärde pühale Rooma Clemensile mälestusrist. Seda rahastas Andrei Rubljovi fond Simferopoli ja Krimmi metropoliidi Lazari õnnistusel. Nagu 


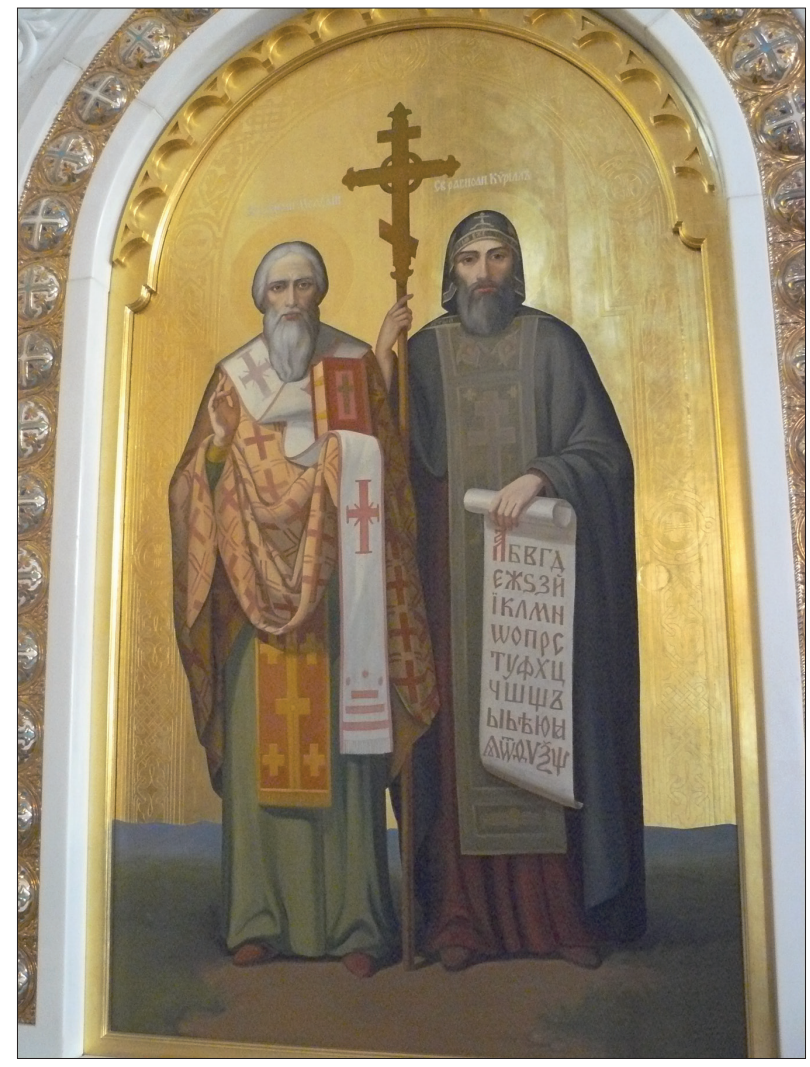

Foto 4. Püha Kirilli ja vend Methodiuse seinamaal püha vürst Vladimiri kirikus. Ekaterina Anastasova foto 2009.

teatas Gumiljovi keskus (tänapäeva euraasianism, liikumine inimõiguste kaitseks ${ }^{14}$ ), ütles kirikuesindaja isa Leonid (Kalinin) risti avamisel: "Mälestusristi rajamisel ei ole mingit poliitilist varjundit. See on puhtalt vaimne aktsioon märkimaks ajaloolise õigluse võitu ning meenutamaks Ukraina ja Venemaa ühist slaavi hinge."

Teksti autor jätkab:

Meenutagem, et Clemens oli Rooma neljas piiskop (paavst), kelle määras Peetrus ise. Püha Clemensit peetakse Venemaa kaitsepühakuks. Tema poole palvetavad inimesed, soovides lastele tervist ja heaolu, perekonnale taasühinemist, armastatute tagasitulekut. ${ }^{15}$ Märter Clemensi säilmed on esimesed kristlikult pühitsetud objektid Venemaal. Püha vürst Vladimir pööras Venemaa [ristiusku] püha Clemensi õiglasel juhtimisel 988. aastal. 
Kahtlusteta on "Ukraina ja Venemaa ühine slaavi hing" osa suurest arutelust "kas Venemaa või Euroopa", mis paneb Ukraina ühiskonda endiselt muretsema.

Võrreldes püha Clemensiga on Kirilli ja Methodiuse mälestuspaik Krimmis palju tagasihoidlikum. Pühakute monument rajati Sevastopolisse linnavalitsuse initsiatiivil alles 2008. aasta 14. juunil, linna päeval (selle ajani ei olnud linnas pühakute järgi nimetatud ühtki objekti), kaastegev oli Sevastopoli bulgaarlaste rahvus- ja kultuurikeskus - organisatsioon Izgrev (Päikesetõus).

Avapidustustel ütles aselinnapea V. Kazarin:

Slaavi tähestik loodi 1145 aastat tagasi. Kirill ja Methodius tutvustasid seda kirjalikult Määrimaal, kuid nende idee ulatub veel kaks aastat varasemasse aega, aastasse $861 \mathrm{pKr}$, mil neile tutvustati nende Hersonesoses viibimise ajal üht vanimat kirjasüsteemi, mis ei ole meie päevini säilinud. Nende tähestik oli kombinatsioon Kreeka ja selle iidse tähestiku vaimust. [---] Meie linn võib olla uhke, et ta ei ole üksnes idaslaavlaste õigeusu häll tänu püha Vladimiri ristimisele Hersonesoses, vaid Sevastopol on ka slaavi kirja häll. ${ }^{16}$

Siiski on püha Clemensi kummardamine oluline nii Sevastopoli ukrainlaste kui ka bulgaarlaste seas (regulaarsed palvused, annetused ja Inkermanis kivikiriku rajamise toetamine), nad kavandavad Kasahhia lahe äärde kabeli või mälestusristi püstitamist. Nagu märgib Sevastopoli bulgaarlaste organisatsiooni esimees:

Siin Krimmis on kõige kuulsam pühak Rooma Clemens (ja tema lugu). Eelmisel aastal me rajasime Kirilli ja Methodiuse mälestusmärgi, 24. mail jätsime lilled. Siiski ei ole inimesed kuigi kursis nende pühakutega. Püha Clemens on kohalik pühak ja seetõttu peaksid siinsed inimesed temast rohkem teadma. ${ }^{17}$

Tegelikult on vendade Kirilli ja Methodiuse austamine osa teisest paradigmast, mis on seotud rahvusliku ajaloo idee ja nende tegevusega Ukrainas.

\section{Rahvuslikud mõõtmed}

Ukrainas, nagu Bulgaariaski, on pühade vendade pidustustel kaks mõõdet: ilmalik pidu ja kiriklik (religioosne) püha.

Bulgaarias moodustus ja kinnistus vendade kultus Bulgaaria taastumise protsessis ja see põhineb kolmel bulgaaria rahvuslikkuse ideega seotud alusel:

- keskaegse Bulgaaria majesteetlikkus, bulgaaria kultuuri nn kuldaeg ja Bulgaaria riigi põhjapanev roll slaavi õigeusukiriku loomisel; 
- Bulgaaria panus Euroopa kultuuri arengusse;

- Bulgaaria taassünd ja tänapäevase Bulgaaria riigi loomine.

Püha on nii populaarne, et viimastel aastatel on Bulgaaria meedias kerkinud küsimus selle kehtestamisest rahvuspühana.

Ukrainas on olukord siiski teistsugune. Vendade Kirilli ja Methodiuse kummardamise juured on ühelt poolt seotud slavofiilsuse ja Venemaa messianistliku rolli ideega slaavi maailmas. Teisest küljest leiame 1845. aasta lõpus või 1846. aasta alguses Kiievis loodud salajase poliitilise organisatsiooni Kirilli ja Methodiuse Vennaskond, mida jagus ainult 14 kuuks. Vennaskonda peetakse Ukraina esimeseks poliitiliseks organisatsiooniks, mille kaudu Ukraina intelligents püüdis võidelda Ukraina rahva õiguste eest. Organisatsioon järgis Vene dekabristide ideid, kuid nõudis mitte üksnes pärisorjuse kaotamist ja poliitilise süsteemi liberaliseerimist, vaid seisis ka ühtsesse Kiievi juhtimise all olevasse Panslaavi föderatsiooni koondunud slaavi rahvaste rahvusliku ja kultuurilise identiteedi eest. Ukraina, Venemaa, Poola, Serbia ja Bulgaaria peaksid saama Panslaavi föderatsiooni liikmeteks. Organisatsioon sai alguse Kiievi Ülikoolist ja sellel oli umbes tosin liiget, kaasa arvatud ukraina kirjandusklassik Tarass Ševtšenko. Vennaskonna programmilisi dokumente "Jumala tegu. Ukraina inimeste elu raamat" ja "Püha Kirilli ja Methodiuse Slaavi Ühingu statuut" (Slaavi ühiskonna statuut) -, mille on kirjutanud organisatsiooni rajaja, hilisem ajalooprofessor Nikolai Kostomarov (tol ajal Kiievi Ülikooli dotsent), peetakse ukrainofiilia (vt üksikasjalikumalt Zajontškovski 1959, Simonova 1990: 341-66) või Ukraina natsionalismi alguseks. Üks organisatsiooni liige Panteleimon Kuliš on Ukraina esimese ajaloo (Povest' ob ukrainskom narode, 1846) ja ukraina keele esimese grammatika autor. Teiste sõnadega tähendab püha Kirilli ja Methodiuse vennaskond vaatamata lühikesele eksistentsile (hiljem kujutas Vene keisririigi propaganda selle tegevust slavonofillsena) Ukraina taasloomise algust.

Kuivõrd Kirilli ja Methodiuse idee pärines algselt Ukrainast, on see ilmselt seotud rahvuslike, poliitiliste ja riiklike sõnumitega, eriti praeguste geopoliitiliste väljakutsete ajal. Usuorganisatsioonid on üksiti ka poliitiliste sõnumite kuulutamise paik. Pärast demokraatlikke muutusi religiooni vallas jagunes ka riik: suurem osa Ukraina kirikutest allub Moskva patriarhaadile (Moskva Patriarhaadi Ukraina Õigeusukirik), uus Ukraina Õigeusukirik allub Kiievi patriarhaadile (eraldus Moskva Patriarhaadist 1992. aastal), mille mõjuvõim on tunduvalt väiksem.

Nii ilmalikku kui ka religioosset püha tähistatakse 24. mail. Tähistamine algas 1994. aastal Ukraina kultuuriministeeriumi ja Ukraina slavistide komitee ettepanekul ning Ukraina ministrite kabineti toel. Tähistamise riigipühana kinnitas president Leonid Kutšma dekreet 2004. aastal. 
Seoses riigi ülesehitamise protsessiga peab märkima, et Ukrainas, nagu ka kogu postsotsialistlikus ruumis, leiab aset rahvuslike, riiklike ja usupühade ajakohastamine, et peegeldada uut ideoloogilist ja poliitilist situatsiooni (Anastasova 2012a: 156-169). Nii näiteks tähistab Ukraina lisaks 24. maile ukraina kirja ja keele päeva 9. novembril ajaloolase Nestori auks, keda Ukraina uus teadus peab Ukraina ajaloolaseks ning vendade Kirilli ja Methodiuse järgijaks. Püha tähistatakse riigipühana alates 1997. aastast kooskõlas president Leonid Kutšma dekreediga "vastu tulles ühiskondlike organisatsioonide initsiatiivile ning arvestades ukraina keele olulist rolli Ukraina ühiskonna konsolideerimisel" (Dekreet 1241/97, 06.11.1997).

Lisaks võib slaavi kultuuriga seotud pühade ritta panna ka slaavlaste sõpruse ja ühtsuse päeva, mida tähistatakse 25. juunil. See seati sisse 1990. aastatel "vastuseks Nõukogude Liidu lagunemisele" ning seda tähistatakse Venemaal, Valgevenes ja Ukrainas. Kultuurifestivali "Slaavi ühtsus" (Venemaal Brjanski linnas) korraldatakse samuti sellel päeval. Pidustuste aluseks sai rahvusvaheline slaavi nooruse festival, mida korraldati NSV Liidus igal aastal alates 1957. aastast. 2002. aastal esitas festival Venemaa, Valgevene ja Ukraina valitsusele deklaratsiooni referendumi kohta eesmärgiga ühendada kolm riiki. Neis kõigis esitletakse püha omapärase Kirilli ja Methodiuse päeva tähistamise kokkuvõttena.

Kolme püha sõnum on ilmselge: rahvuslikust ukraina kirjanduse ja keele päevast panslavistliku ausa sihini sulandada kolm idaslaavi riiki. Loomulikult kasutatakse pühasid ja nende sõnumeid erinevates poliitilistes olukordades. Näiteks slaavlaste sõpruse ja ühtsuse päeva tähistatakse rohkem Ukraina idaosas, kus kõneldakse peamiselt vene keelt. Venemeelse Ukraina Regioonide Partei aseesimees (Regioonide Partei algatatud on seadus, mis kinnitas vene keele piirkondlikuks keeleks) Vadim Kolesnitšenko ütles 2010. aastal:

On ülimalt tähtis, et Ukraina tähistab slaavlaste sõpruse ja ühtsuse päeva vahetult enne riigi keelepoliitika alustalasid käsitleva seaduse teist lugemist. [---] See püha on väga tähtis, kuivõrd see ühendab erineva kultuurilise taustaga slaavlasi. See on vastuvaidlematu meenutus, et me võime ja peame rääkima eri keeli, kaasa arvatud vene ja ukraina keel. Ja see ei tohiks põhjustada midagi muud peale vastastikuse austuse, üksteise toetamise ja ühise rõ̃omu, et meil on nii sügavad juured - mitte üksnes ajaloolised, vaid ka humanitaarsed ja lingvistilised. ${ }^{18}$

Kroonik Nestori päeval viiakse Kiievis monumendi juurde lilli, kõlavad pühalikud sõnad, autasustatakse "Ukraina sõna parimaid edendajaid" ja tunnustatakse kirjastajaid, kes avaldavad trükiseid ukraina keeles. Selle püha paiku korraldatakse ukraina keele ekspertide rahvusvaheline võistlus "Petro Yatsik". 


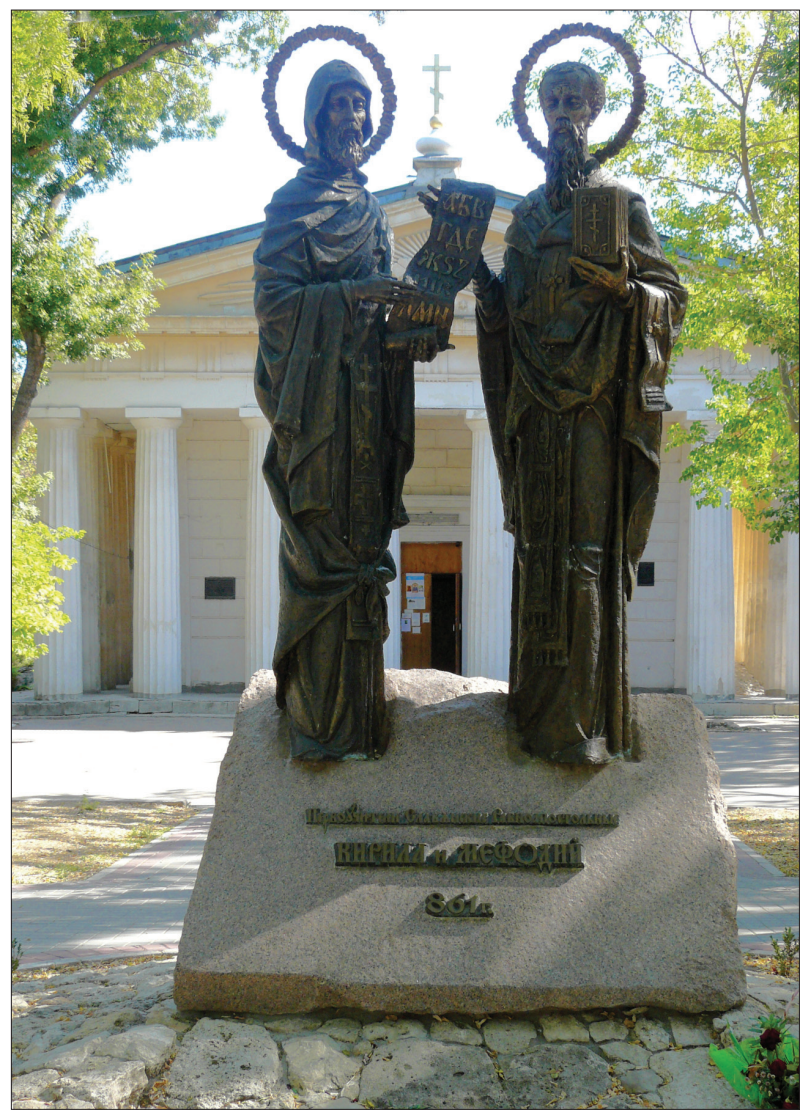

Foto 5. Pühale Kirillile ja Methodiusele püstitatud mälestusmärk Sevastoopolis (Krimm). Ekaterina Anastasova foto 2009.

Esimest korda korraldati see võistlus 2000. aastal Nadežda Yatsiku (Kanada ärimehe, etnilise ukrainlase, patrooni ja filantroobi Petro Yatsiku ${ }^{19}$ tütar) ja tema juhitava haridusfondi P. Yatsik patroneerimisel. 2006. aastal loobus fond võistlusest N. Yatsiku avaldusega, et "Ukraina diasporaa ei saa päästa ukraina keelt Ukrainas. Seda saab teha ainult Ukraina valitsus".

Vendade Kirilli ja Methodiuse päeva tähistatakse nii pealinnas Kiievis kui ka teistes linnades, kus on nende monumendid (Odessa ja Sevastopol) ühesuguse skeemi järgi. Vendadele pühendatud pidustusi külastasid teiste hulgas Bulgaaria diplomaatilise korpuse esindajad (vt allpool). Pidustustega kaasnevate ürituste seas võime märkida koolipühasid etniliste bulgaarlaste külades (Bessaraabias, Krimmis, Aasovi piirkonnas), viktoriine, võistlusi ja konkursse. 
Bulgaarlastest üliõpilased osalevad võistlusel ja pidustustel, mida korraldavad ülikoolides Bulgaaria rahvuslik-kultuurilised ühingud. Pidustuste osana korraldatakse mitmes Ukraina linnas Kirilli ja Methodiuse loengud.

Tõenäoliselt sügavaim on vendade Kirilli ja Methodiuse austamise traditsioon Odessas, kus pidustuste juured on religioonis ning ulatuvad 19. sajandi lõppu ja 20. sajandi algusse. Tänapäeval on linnas kasutusel püha kolm põhivormi:

- religioosne - patroonipüha kahes kirikus;

- kümnepäevane bulgaaria kultuuri festival, mille korraldab Bulgaaria diplomaatiline korpus Odessas 24. mai paiku;

- bulgaaria diasporaa püha - koolivaheaeg Odessa piirkonnas etniliste bulgaarlastega asustatud külades, Bulgaaria konsulaadi toel kohalike bulgaaria organisatsioonide korraldatud pidustused (näitused, kontserdid, akadeemilised konverentsid, viktoriinid jne).

Linnas on pühadele vendadele mälestusmärk, mis avati 24. mail 2007. Nagu kinnitati selle avamisel, "sümboliseerib monument Ukraina ja Bulgaaria sõprust”. See asub Odessa Riikliku Ülikooli humanitaarkorpuse ees, kus on õppinud sellised Bulgaaria poeedid nagu Ivan Vazkov ja Hristo Botev ning tänapäeval omandab siin haridust tosinaid Bulgaaria päritolu üliõpilasi.

\section{Odessa vaimulik kool}

Slaavlaste õpetajate, püha Kirilli ja püha Methodiuse tempel rajati Odessasse 1882. aastal, mil sinna ehitati Odessa vaimulik kool, mis avamisest peale on olnud äärmiselt populaarne ilmikute seas:

Kuigi lähedal asus Peetri ja Pauli katedraal ning Ülestõusmise tempel seisis Staroportofrankovska ja Kolontajevska tänava ristil, oli püha Kirilli ja Methodiuse tempel alati rahvast täis. Pühade ajal ei suutnud kirik mahutada kõiki Kirilli ja Methodiuse kummardajaid, sest neid peeti üliõpilaste valvajateks ja laste pühakuteks” (Anissimov 2005: 23).

Templil on keeruline ajalugu: seda on suletud ja taasavatud mitu korda. 1933. aastal arestiti "usulised väärisesemed riigi kasuks" ja kirik suleti, kuid (erinevalt kahest eelmainitud kirikust) seda ei hävitatud, kuivõrd see oli hoone osa. Teise maailmasõja ajal avati see Rumeenia valitsuse ajal uuesti, lõplikult suleti aga 1953. aastal, mil Nõukogude valitsus muutis selle spordihooneks. Tempel taastati järk-järgult alates 24. maist 1996 kuni 24. maini 2003 (Anissimov 2005: 30). 
Tänapäeval, just nagu asutamise ajal, külastavad seda "ümbruskonna kirikut" linna õigeusklike esindajad: venelased, ukrainlased, kreeklased, bulgaarlased jne.

\section{Sõjakool - poliitika ja usk}

Pühakute Kirilli ja Methodiuse templil on sõjakooliga pikk ühine ajalugu. Algselt oli pühadele vendadele, teaduse patroonidele pühendatud tempel ehitatud Odessa kadetikorpuseks (loodud Vene imperaatori Nikolai II korraldusel 1899. aastal), see õnnistati sisse 1902. aastal. 1917. aastal muudeti see sõjakooliks. 1941. aastast sai sellest Odessa jalaväekool ja pärast selle hinguseleminekut Odessa Polütehnilise Ülikooli (loodud 1918) osana sõjandusinstituut. Nii sotsialismiperioodil, mil instituut oli kogu NSV Liidu kõige prestiižikam sõjakool, kui ka tänapäeva sõjaakadeemiana (2011) on see piirkonna sõjaväelise eliidi ja vaimulikkonna (sõjaväe kirikute ja kabelite vaimulikud) keskus.

\section{Pühakute Kirilli ja Methodiuse kiriku patroonipüha Odessa Maavägede Akadeemias}

Pidulik liturgia, mille viib läbi Ukraina vaimulikkonna üks austatumaid isikuid, Odessa ja Izmajili piirkonna piiskop Agafangel, ja sellele järgnev lõunasöök kõigile osavõtjaile (kooli õpetajad ja üliõpilased) on Odessa vene keelt kõneleva kogukonna pidu (Odessa on traditsiooniliselt venekeelne linn). Etnilised bulgaarlased tähistamisel ei osale, ja nagu selgus, külastavad nad seda pühakoda harva.

Piiskop Agafangel (Odessa ja Izmajili piiskopkonna piiskop alates 1992. aastast) ei ole üksnes vaimne inimene, ta on ka väga aktiivne ühiskonna- ja poliitikategelane. Aastatel 1990-1994 oli ta Ukraina Raada populaarne liige ja 2006. aastal Odessa piirkonnas venemeelse Regioonide Partei nimekirja esinumber, olles selle esindaja piirkonnavalitsuses kaks järjestikust ametiaega. ${ }^{20}$ Ta on Ukraina õigeusu kiriku lõhenemise (vaimulikkonna osa eraldumine Moskva patriarhaadist) ägedamaid vastaseid. Vaimulik on Odessa piirkonna poliitikaelus ere tegelane, kelle poliitilised seisukohad aitavad vormida avalikku arvamust. Vene ajakirjaniku ja raadiojaama Ehho Moskvõ peatoimetaja Aleksei Venediktovi sõnad annavad tunnistust piiskopi isiksusest ja tema mõjust Odessa avalikkusele: “Ta on põhimõtete ja karismaga mees. Ma arvan, et Regioonide Partei võit Odessas on kahtlemata tema teene."21

Agafangel kommenteerib alati Venemaa ja lääne (Euroopa Liit ja NATO) vastasseisuga seotud jooksvaid sündmusi Ukrainas: 


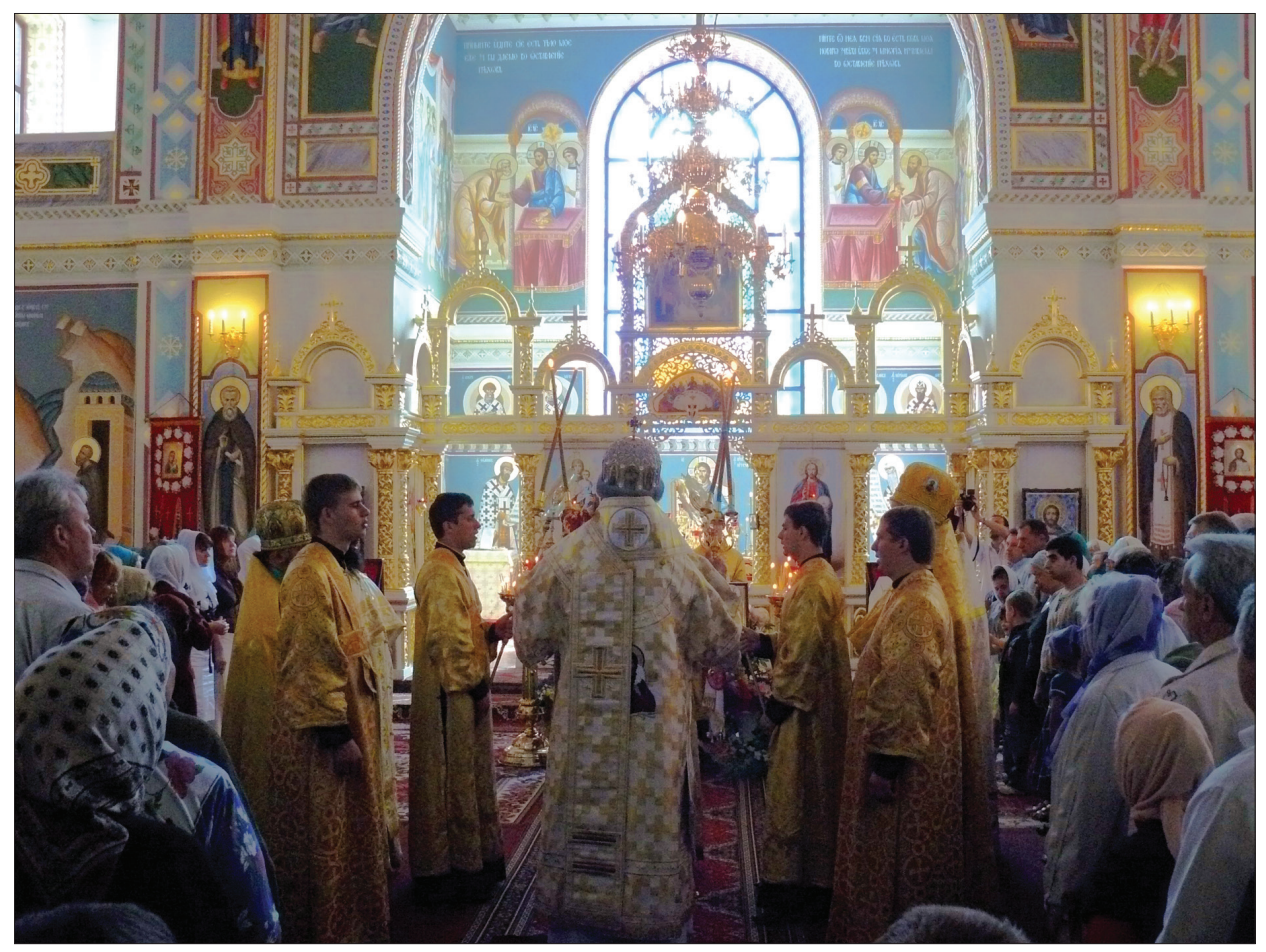

Foto 6. Jumalateenistus püha Kirilli ja Methodiuse auks piiskop Agafangeli osavõtul 24. mail 2009. Ekaterina Anastasova foto 2009.

"Õigeusu kirik on mures Ukraina seotuse pärast alliansiga (NATO), mis on oma olemuselt topeltstandardeid kuulutav metsalise organisatsioon [minu rõhutus - E. A.]”; "koolid õpetavad lastele, et allianss muudab meid Euroopa riigiks, kuigi me asume keset Euroopat. Ka meil on palju oma lastele õpetada, meil on kultuur, religioon, moraaliprintsiibid”; "me näeme selle üksuse tegevust Kosovos, me näeme, mida on tehtud Venemaale. NATO - see on veri, sõda, pisarad". ${ }^{22}$

Temale kuuluvad avaldused, mida sageli nimetatakse skandaalseteks: "NSV Liit on meie kõigi kodumaa" ja "Lviv" ${ }^{23}$ on meie Tšetšeenia"24.

Mais 2009 lülitas ta oma pidupäevajutluses Kirilli ja Methodiuse tegevuse tänapäevasesse poliitilisse konteksti:

Kirill ja Methodius pärandasid slaavi rahvastele vennaskonna... Täna tõstame oma palved Jumala trooni ette. Pühakud Kirill ja Methodius palvetasid koos meiega. Me palume Jumalal tugevdada meie vennalike slaavi rahvaste ühtsust, hoida vaenulikke jõude Ukrainas, Venemaal ja 


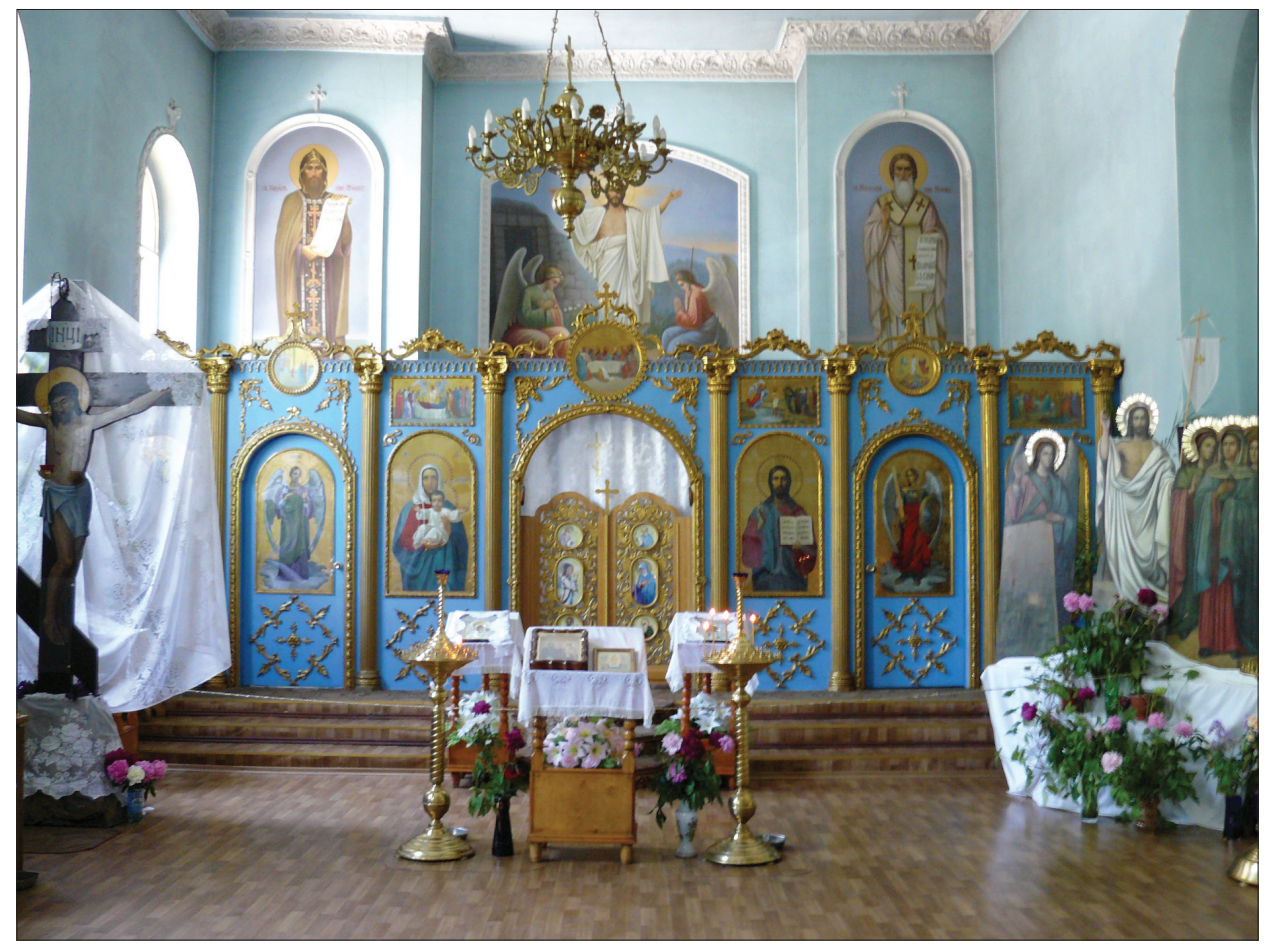

Foto 7. Püha Kirilli ja Methodiuse kiriku interjöör. Odessa. Ekaterina Anastasova foto 2009.

Valgevenes meie inimeste seas konflikte tekitamast. Ja me usume, et nende pühakute, slaavlaste õpetajate palvete abil elavad meie inimesed ohutult üle praegused rasked ajad ja kurjus, mis pü̈̈ab meie ajalugu ümber kirjutada, tõmbub tagasi. Nende aeg on ümber. Varsti tulevad uued jõud, kes peatavad selle julma vaenukülvamise Venemaa, Ukraina ja Valgevene inimeste seas. Me kõik - venelased, ukrainlased ja valgevenelased - oleme vastu võtnud püha ristimise samas "Dnepri jõe ristimiskarikas". Me jagame sama õigeusu usku, sama kultuuri, sama ajalugu. ${ }^{25}$

Need sõnad osutusid prohvetlikeks, kui Regioonide Partei saavutas Ukraina 2009. aasta valimistel võidu.

Kui piiskopile ja pühade vendade sõjaväelisele eliidile on pühad vennad praeguste poliitiliste sõnumite sümbolid, on pühakute pidustustel ilmikute silmis (osa religioossest ja sõjaväelisest eliidist) teistsugune tähendus. Ühest küljest nähakse neis patroonipühakuid, ja kes on nende järgi nime saanud, tähistavad sel kuupäeval oma nimepäeva (inglipäeva) või külastavad oma lah- 
kunud lähedaste mälestuseks pühakoda. Pühakoda külastavad need inimesed, kelle lähedased surid pühade vendade päeval, et paluda oma lähedastele kaitset Jumala ees. Teisest küljest arvab suurem osa pidustustel osalejatest, et Kirill ja Methodius on eelkõige pühakud:

- slaavlaste patroonid ja kaitsjad;

- kõige arusaadavama ja Jumalale lähedasema (kättesaadavama) keele slaavi keele - loojad.

Selline arusaam pühakutest on seotud vahendamise ning isiku ja riigi vaheliste suhete propageerimisega - Jumal ei ole esiplaanil Bulgaaria diskursuse massi (ilmikute) ega Odessa noorte etniliste bulgaarlaste silmis. ${ }^{26}$ Viimased näevad pigem vendade valgustusfunktsioone - neid kui slaavi tähestiku loojaid. Hoolimata tihedatest sidemetest Bulgaaria peakonsulaadiga Odessas, mis väljendub Bulgaaria riiklikus seisukohas pühadest vendadest, kelle töö "teeb uhkeks iga bulgaarlase, et nad andsid maailmale midagi nii olulist", ${ }^{27}$ kannavad Kirill ja Methodius noorte Bessaraabia bulgaarlaste silmis erinevaid endeid. Traditsiooniliste seisukohtade, nagu "slaavi tähestiku loojad" ja "on hea, et nad lõid tähestiku", kõrval esinevad ka teistsugused arvamused: "Kirill ja Methodius olid slaavlased, nad ei olnud bulgaarlased" ja üllatavalt: "Võib-olla oleks olnud parem, kui nad poleks seda tähestikku loonud, siis ei oleks praegu neid vastasseise: Euroopa ja Venemaa, ladina ja kirillitsa... Ja me oleksime rohkem ühendatud." 28

\section{Kokkuvõtteks}

Algusest peale on Kirilli ja Methodiuse töö, samuti selle uuendused slavofiilsuse ja erinevate rahvuslike liikumiste tekke jooksul 19. sajandi slaavi riikides, olnud poliitilise iseloomuga. Huvitaval kombel säilitab see postmodernistlike geopoliitiliste murrangute ajal oma poliitilise mõõtme mitte üksnes riiklikul tasemel, vaid ka religioossest aspektist. Vendi kasutatakse argumendina vaidlustes: Bulgaariale, Euroopa Liidu liikmesriigile, on nad osa Euroopa kultuuripärandist, aga Ukrainale on nad rahvusliku taassünni sümboliks ja argumendiks, mis kinnitab Venemaa ja slaavi riikide vendlust vastukaaluks NATO-le, Euroopa Liidule ja USA-le.

2014. aasta kauakestev protest Euromaidan Kiievis (sai alguse 21. novembril 2013) algas Euroopa Liiduga peetud läbirääkimiste peatumise ja president V. Janukovitši keeldumise tõttu kirjutada Vilniuses korraldatud partnerluskohtumisel alla assotsiatsioonileping Euroopa Liiduga. Järgnenud poliitiline kriis, Krimmi ühinemine Vene Föderatsiooniga ja hilisem verine kodusõda said maailmas peamisteks uudisteks. Taas ilmus lavale selle artikli üks peatege- 


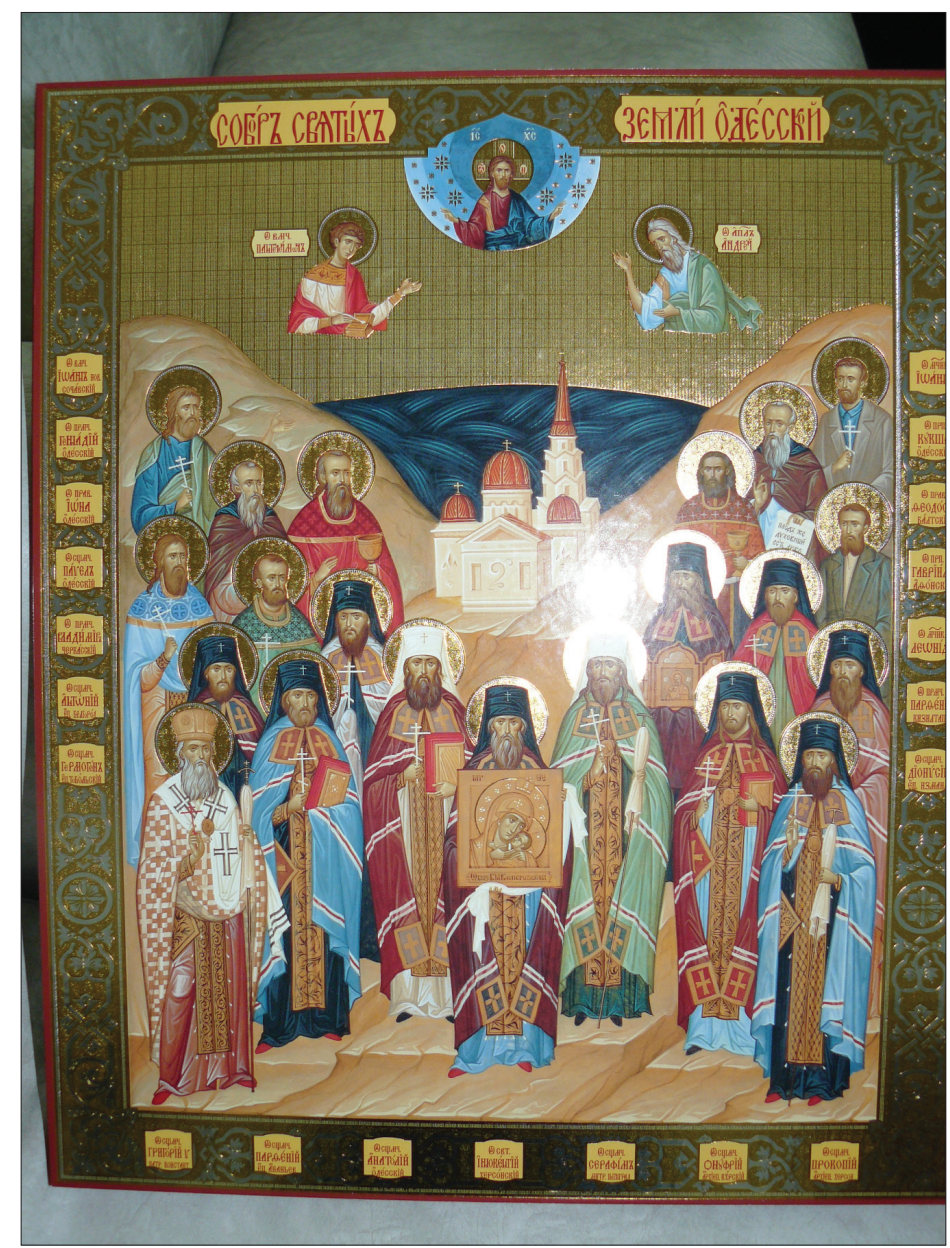

Foto 8. Odessa uute pühakute ikoon. Ekaterina Anastasova foto 2009.

lasi - metropoliit Agafangel. Püha Jüri säilmete Odessasse saabumise auks korraldatud jumalateenistusel ütles ta:

Püha Jüri parem käsi saabus Ukrainasse segaduste ajal, eriti Kiievis Maidanil, kus põrgujõud kogunevad et purustada meie süsteem, luua segadust, viha ja lõhet inimeste vahele... kuid pühaku palvete abiga noomib Jumal rumalaid, toob rahu ja harmoonia ühiskonda... Me usume, et tugevam jõud võidab. ${ }^{29}$

Ukraina ladviku avaldustes omandavad poliitiline, sotsiaalne ja majanduslik kriis apokalüptilised mõõtmed: 
Me teame, et esimene revolutsionäär oli kurat, revolutsioone panevad toime põrgujõud. Seda, millele meid täna kutsub üles Euroopa, nimetavad õigeusklikud Eurosoodomaks. Euroopa sunnib meile peale kristlike väärtuste jalge alla tallamist, samasooliste abielu sisseseadmist õiguseta seda kritiseerida [---], laste väärkasvatust koolis, ning mis peamine-meil soovitatakse lahkuda õigeusu tsivilisatsioonist ja muutuda protestantlikkatoliikliku tsivilisatsiooni äärealaks, tänapäeva agressiivselt ilmalikuks antikristlikuks tsivilisatsiooniks, kus tähtsaks jõuks on agressiivne islam. Ma leian, et tõeline Euroopa, kristlik Euroopa on säilinud üksnes Venemaal. Ja ainult koos suudavad Venemaa, Valgevene, Ukraina ja Moldova saada õigeuskliku tsivilisatsiooni keskmeks, mis peatab selle seadusetuse, mis maailmas toimub. ${ }^{30}$

Ilmselt on S. Huntingtoni tsivilisatsiooniterminoloogia lähedane Ukraina Venemeelsele vaimulikkonnale, kes pühitses geopoliitilise vastasseisu, kasutades fundamentaalset opositsiooni Jumal ja Kurat (Venemaa ja õigeusklik maailm vs Euroopa Liit).

Kasutatakse keskaegset tehnikat, milles ajaloolise saatuse, etniliste pingete ja Ukraina postsovetliku nostalgia toel joonistub välja ambitsioonikas postmodernne projekt. Projekt, milles Kirill ja Methodius kui slaavlaste ühendajad leiavad taas oma koha.

Tõlkinud Asta Niinemets

\section{Kommentaarid}

1 Artikkel on kirjutatud Bulgaaria Vabariigi Teadus- ja Haridusministeeriumi teadusfondi projekti DOO2-315/19.12.2008 nr 1/17.12.2010 "Püha Kirilli ja Methodiuse püha - rahvuslikust Euroopa vaimsesse ruumi" raames.

2 Mainimist väärivad Methodiuse klooster tänapäeva Türgi linna Bursa piirkonnas, tema eksiil Saksamaal (keskaegne Švaabimaa) jne.

${ }^{3}$ Kirjalike allikate andmetel tunnistas Bulgaaria kirik vennad pühakuteks juba keskajal.

4 Sõna Ukraina kasutati esmakordselt Ipatjevi kroonikas (1187). Teise tõlgenduse kohaselt pärineb riigi nimi Ukraina ukrainakeelsest nimisõnast краінa, mis tähendab maad.

5 Geograafiline termin, mida kasutati 14. ja 15. sajandil seoses Galiitsia-Volõõnia vürstiriigiga ja alates 16. sajandist seoses Edela-Venemaa piirkondadega. 17. sajandist 20. sajandi alguseni kasutati seda Venemaal geograafilise piirkonna ja Malorossijskaja kubermangu nimetamiseks. Termin Ukraina kiideti heaks nõukogude ajal.

6 Uniaatidel on kasutusel õigeusukiriku praktika, kuid kirik allub paavsti jurisdiktsioonile. 
7 Odessa piirkonna omavalitsuse andmed septembrist 2013 (rahvusvaheline konverents "Polüfoonia vs kakofoonia: rahvuslik ja usuline mitmekesisus Odessa piirkonna rahvastikus piirkondliku demokraatia kontekstis", 12.-14. septembrini 2013 Odessa Riiklikus Ülikoolis).

8 Mihhail Gruševski (ukr Mihailo Gruševski, 1866-1934) - üks Ukraina rahvusliku liikumise liidreid, Ukraina Keskraada esimees, ajaloolane, Lvivi Ülikooli professor 1894-1914, akadeemik. - Tlk.

9 Püha Clemensi jäänuste leidmise ajal kandis Kirill veel oma ilmiknime Constantinus.

${ }^{10}$ Väljakaevamised on kinnitanud, et selles piirkonnas ei ole olnud marmorikaevandusi.

${ }^{11}$ Sündmuste ülevaade ilmus pealkirja all "Eestpalve Clemensi kuulsusrikaste säilmete hoidmiseks", see on omistatud pühale Kirillile. Vt näidet Begunov 2006: 5.

12 "Krimmi" Clemensi kuju põhjaliku uurija, autoriteetse Bütsantsi-spetsialisti, vaimuliku professori Dimitri Spiridonovi (1871-1938) lugu on traagiline. Ta lasti maha 1938. aastal Stalini režiimi ajal, 2000. aastal kuulutas Vene õigeusu kirik ta Krimmi piiskopkonna ettepanekul pühakuks. Tema päeva tähistatakse Venemaa uute märtrite ja usutunnistajate päeval (esimene pühapäev ajavahemikus 25. jaanuarist 7. veebruarini).

${ }^{13}$ Lugu püha Clemensi "otsingutest" Krimmis on ajalooliste, kirjanduslike ja arheoloogiliste andmete põhjal väga huvitav. Vt rohkem nt Markevitš 1909: 106-114; Sorotšan 2013: 205-225, 240-278.

${ }^{14} \mathrm{http}: / / \mathrm{www}$.gumilev-center.ru/sostoyalos-torzhestvennoe-osvyashheniepamyatnogo-kresta-v-chest-pervogo-russkogo-svyatogo-svyashhennomuchenikaklimenta/\#more-5822 (22.07.2015). Esimese vene pühaku Klementi mälestusristi sisseõnnistamine toimus 24.08.2011.

${ }^{15}$ Püha Clemensi vita andmetel oli ta palju aastaid lahutatud oma armastatud inimestest, kellega ta imepäraselt sai taas oma saatuse tõttu kokku.

${ }^{16} \mathrm{http} / / /$ new-sebastopol.com/news/novosti_sevastopolya/V_Sevastopole_otkryli_ pamyatnik_svyatym_ravnoapostol_nym_Kirillu_i_Mefodiyu_FOTO $(14.06 .2008$, lehekülg ei ole enam leitav).

${ }^{17}$ Pärast Nõukogude Liidu lagunemist Moldovast Sevastopolisse emigreerunud umbes 50aastane Bessaraabia bulgaarlane Saveli Ivanovitš Butškov, Sevastopoli bulgaarlaste assotsiatsiooni Izgrev president. Salvestanud Ekaterina Anastasova ja Grigori Grigorov (edaspidi E. A. ja G. G.) 23.09.2009 Sevastopolis.

${ }^{18} \mathrm{http}: / /$ www.regnum.ru/news/1545035.html (25.06.2012, vaadatud 22.07.2015); vt ka http://www.ukrinform.ua/rus/news/vadim_kolesnichenko_dovolen_chto_den_drugbi_i_ edineniya_slavyan_otmechaetsya_nakanune_prinyatiya_zakona_o_yazikah (25.06.2012, lehekülg ei ole enam leitav); vt ka http://partyofregions.dp.ua/node/126 (25.06.2010, vaadatud 22.07.2015). Seadus võeti vastu 3. juulil 2010. See oli esimene seadus, mis tühistati pärast Euromaidanit.

${ }^{19}$ Petro Yatsik (1921-2001) on Ukraina entsüklopeedia suurpatroon, ta on asutanud Ukraina Instituudi Harvardi Ülikooli (USA) juures ja Ukraina ajaloo õppekeskuse Alberta Ülikooli (Kanada) Ukraina uuringute instituudis. Ta on rahastanud ka ukraina koolide ja kirikute rajamist Brasiilias.

20 2014. aastal pärast president V. Janukovitši (Regioonide Partei) läbikukkumist astus metropoliit Agafangel raadast (parlament) tagasi.

${ }^{21} \mathrm{Vt} \mathrm{http://timer.od.ua/news/odesskij-mitropolit-agafangel-sravnil-lvov-s-chechnej.html}$ (07.06.2011, vaadatud 22.07.2015). 
${ }^{22} \mathrm{http} / / / \mathrm{www}$.misto.odessa.ua/odessa-i-region/2008/09/12/13215/pravoslavnayaobshhestvennost-odessy-protiv-vstupleniya-v-nato.html (12.09.2008, lehekülg ei ole enam leitav).

${ }^{23}$ Lvivi peetakse Lääne-Ukraina keskuseks ja läänemeelsete mõjude kandjaks riigis.

${ }^{24} \mathrm{http} / / /$ www.pravda.com.ua/rus/news/2011/06/7/6275752/(07.08.2011, vaadatud 22.07.2015).

${ }^{25}$ Piiskop Agafangel, 24.05.2009, Odessa, salvestanud E. A. ja G. G.

${ }^{26} \mathrm{Ma}$ kasutan siinkohal materjali, mis on pärit intervjuudest enne pühade Kirilli ja Methodiuse pärast peetud võidujooksu Odessa Riikliku Ülikooli keeleteadlaste ja ajaloolaste vahel, lühiintervjuud kaheksa ajalooüliõpilasega (I-III kursus). 18-23aastased noored Odessa piirkonna etnilised bulgaarlased - 30.05.2009, Odessa, välitööpäevik, E. A.

${ }^{27}$ T. E. Gregory Prodanov, Bulgaaria peakonsulaadi konsul Odessas. 27.05.2009, salvestanud E. A., välitööpäevik.

${ }^{28}$ X. X., 18aastane poiss, esimese aasta üliõpilane, 30.05.2009, salvestanud E. A., välitööpäevik.

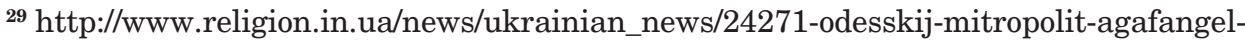
nazval-evromajdan-smutoj-kuda-sobiraetsya-sila-ada.html (12.12.2013, lehekülg ei ole enam leitav).

30 Ülempreester Andrei Novikov, Odessa piiskopkonna sekretär, http://xerson.net/ евромайдан-это-собрание-сил-ада-счи/ (vaadatud 15.07.2015).

\section{Kirjandus}

Anastasova, Ekaterina 2005. "We are Bessarabians here". Identity, Tradition and Power in Southern Bessarabia. The Anthropology of East Europe Review: Central Europe, Eastern Europe and Eurasia 24 (1), lk 59-65.

Anastasova, Ekaterina 2012a. The National Festive Systems in the Post-Socialist Spacebetween Past and Present. Kõiva, Mare (toim). The Ritual Year 6. The Inner and the Outer. The Yearbook of the SIEF Working Group on the Ritual Year. Tartu: ELM Scholarly Press, lk 159-169.

Anastasova, Ekaterina 2012b. Identity of (Trans-) National Minorities in the Nation Building Process (the Case of Ukraine). Hristov, Petko Petrov (toim). Migration and Identity: Historical, Cultural and Linguistic Dimensions of Mobility on the Balkans. Sofia: Paradigma PH, lk 269-278.

Anissimov, Vadim 2005. Zhitie sviyatyh ravnoapostol'nyh Mefodiya i Kirilla, Uchitelej Slovenskih. Odessa: Odesskii palomnik.

Begunov, Juri 2006. Sv. Kliment Rimskii v slavianskoi traditsii: nekotorye itogi i perspektivy issledovaniia. Vizantinorossika 4. Clementiana Nordica: Pochitanie Sv. Klimenta Rimskogo na severe khristianskogo mira. Sankt-Peterburg: Sankt-Peterburgskoe Obshchestvo vizantino-slavianskikh issledovanii, lk 1-61.

Huntington, Samuel P. 1999. Sblasakat na tsivilizatsiite i preobrazuvaneto na svetovniya red. Sofia: Obsidian. [1996. The clash of civilization and the remaking of world order. New York: Simon \& Schuster.] 
Kerov, Valeri 2013. “Ukraina - Russ", “finno-ugorskie kolonii” i belorusskie natsional'nye obychai: obosnovanie natsional'nogo suvereniteta $\mathrm{v}$ ofitsial'nykh uchebnikakh po natsional'noi istorii Ukrainy i Belarusi. Vestnik Rossiiskogo universiteta druzhby narodov. Seriia Istoriia Rossii 1, lk 124-132.

Markevitš, Arseni 1909 = Markevich, Arseni. Ostrovok v Kazachei bukhte, kak predpolagaemoe mesto konchiny sv. Klimenta, papy Rimskogo. Izvestiia Tavricheskoi uchenoi arkhivnoi komissii 43, lk 106-114.

Simonova, Inna 1990. “Zagovorshchiki”. Iz istorii odnogo nesostoiavshegosia politicheskogo protsessa. Istoki (Al'manakh) 22, lk 341-366 (http://ruskline.ru/analitika/2006/06/09/ zagovorwiki/ - 16. juuli 2015).

Sorotšan, Sergei 2013 = Sorochan, Sergei. Vizantiiskii Kherson (vtoraya polovina VI pervaia polovina $X v v$. Ocherki istorii i kul'tury 3. Khar'kov-Moskva: Russkii Fond Sodeistviia Obrazovaniiu i Nauke.

Spiridonov, Dmitri 1909. K voprosu o muchenii Klimenta, papy Rimskogo, v Krymu. Izvestiia Tavricheskoi uchenoi arkhivnoi komissii 43, lk 115-124.

Zajontškovski, Pjotr 1969 = Zaionchkovskii, Petr. Kirillo-Mefodievskoe obshestvo (18461847). Moskva: Izd-vo Moskovskogo Universiteta.

Tolstoi, Nikita 1988. Drevniaia slavianskaia pis'mennost' i stanovlenie etnicheskogo samosoznaniia u slavian. Tolstoi, Nikita. Istoriia $i$ struktura slavianskikh literaturnykh iazykov. Moskva: Nauka, lk 128-140. (http://www.inslav.ru/images/stories/pdf/1988_ Tolstoj.pdf - 16. juuli 2015).

\section{Summary}

\section{The Feast of Sts. Cyril and Methodius in Bessarabia and Crimea, Ukraine}

\section{Ekaterina Anastasova}

Keywords: European Union, Russia, St. Clement, St. Cyril and Methodius, Ukrainian revival

The feast of Sts. Cyril and Methodius (May 11-24) and the life and work of the two brothers occupy a central place in the Bulgarian national paradigm. Their life and work are celebrated by all Slavic nations (with different accents and on different dates in the national/church calendars). The feast is celebrated among the Bulgarian Diaspora in Ukraine (the largest Bulgarian community outside Bulgarian boarders) and it also has a place in the official state calendar of the country.

This paper deals with the celebrations of the feast in Bessarabia (Odessa) and Crimea (Sevastopol), Ukraine, among the Bulgarians and Ukrainians; the life stories of the two brothers; interpretations of their origin, works, and significance for the Slavic cultures of both communities (Bulgarians and Ukrainians). The analysis shows the dynamics of interpretations of the lives and work of the two saints in different national paradigms and state priorities. 